Article

\title{
Sustainable Cities: A Reflection on Potentialities and Limits based on Existing Eco-Districts in Europe
}

\author{
Marta Bottero $₫$, Caterina Caprioli * $\bullet$, Giancarlo Cotella $₫$ and Marco Santangelo \\ Politecnico di Torino, Interuniversity Department of Regional and Urban Studies and Planning (DIST), \\ Viale Mattioli 39, 10125 Torino, Italy; marta.bottero@polito.it (M.B.); giancarlo.cotella@polito.it (G.C.); \\ marco.santangelo@polito.it (M.S.) \\ * Correspondence: caterina.caprioli@polito.it; Tel.: +39-0110906468
}

Received: 31 May 2019; Accepted: 10 October 2019; Published: 18 October 2019

\begin{abstract}
The need for more sustainable cities has become a primary objective of urban strategies. The urgency for a radical transition towards sustainability in a long term-vision has brought with it several new concepts, such as smart urbanism, and models, such as smart city, eco-city, sustainable neighborhood, eco-district, etc. While these terms are fascinating and visionary, they often lack a clear definition both in terms of theoretical insight and empirical evidence. In this light, this contribution aims at defining a conceptual framework through which to further substantiate the blurred concept of eco-district and sustainable neighborhood. It does so by reviewing the concepts of smart urbanism and sustainable neighborhood/eco-districts in the literature, including also references to other well-known sustainability-oriented models of urban development. It then explores whether several indicators, emerging from the analysis of exemplary case studies of sustainable neighborhoods in Europe, can be used to clearly identify the characteristics of a sustainable approach at the district scale. The analysis, built on a review of existing literature, allows for both the clarification of several issues related to these fields of inquiry, as well as for the identification of the potential bridges to link these issues.
\end{abstract}

Keywords: smart urbanism; sustainable neighborhood; eco-district; indicators; urban design energy transition; post-carbon cities

\section{Introduction}

In recent decades, with the increasing awareness of the fundamental role of sustainability issues and the necessity of long-term perspectives in the field of urban transformation and planning, a variety of new concepts and paradigms have started to populate the scientific debate. Terms like smart city, eco-city, smart urbanism, sustainable neighborhood, eco-district-just to name a few-have become part of everyday language, often generating overlapping and misunderstanding.

Despite this, the urgency for a radical change in our way of approaching urban development is not in question. Cities and urban areas continue to attract people-the United Nations predicts that over $60 \%$ of the world's inhabitants will live in urban areas by 2030 [1] —and consume $60-80 \%$ of the world's total energy [2]. At the same time, cities still represent a flourishing environment for technological, economic and socio-cultural development [3], which is the testbed for any important change that can impact human life on the planet.

The context that emerges is thus extremely complex. A variety of aspects must be taken into consideration by decision-makers dealing with urban transformation; aspects that go from economic to environmental issues, from energy to social aspects, with a long-term vision aiming at sustainable development [4-8]. For this reason, it is not surprising that the different concepts and paradigms proposed to achieve sustainable urban development are rather fuzzy in their definition, and often characterized by scopes that are blurred and overlapping. 
A first issue that should be considered is related to the concept of smart urbanism that is considered by Luque-Ayala and Marvin [9] as "emerging at the intersection of visions for the future of urban places, new technologies and infrastructures" (p. 2105). Smart urbanism, therefore, is placed at a crucial crossing to understanding the shape that cities can take because of their interaction with new technologies and infrastructures. From a certain perspective, it may be considered to be related to urbanization processes, while the debate on smart cities, which slightly anticipates the one on smart urbanism, seems to be more related to the definition of urban models or paradigms for change [10,11].

Dealing with the shape of cities does not necessarily mean that the only urban morphology has a role: the way cities change, in fact, does impact and is affected by all sorts of symbolic, immaterial and intangible aspects of urban life (lifestyles, for instance, have a great role in orienting in one direction or the other the possible choices of transformation in cities, as well as power relations) [12-14]. However, the adaptive process of cities to new technologies and the often-related infrastructures do indeed have a physical impact. Furthermore, for moving away from a generic reference to "new technologies" and "infrastructures", it might be considered that the majority of such references regard either energy-related issues (smart grids, smart meters, etc., especially from the point of view of institutions and enterprises; see for instance the EU SET-Plan, 2017 [15,16], or urban data (gathering, storing, interpreting data, etc.)) [17]. This purely technology-driven paradigm has been criticized in recent literature contributions, highlighting the need to enlarge the focus to urban outcomes, rather than to technology in isolation, and hence to consider other aspects such as urban metabolism, culture and governance [18]. Additional insights concern the specific sectoral declination of the smart city paradigm, as highlighted, for instance, by several contributions focusing on the role of smart tourism in sustainable urban development in developing countries [19] or on the links between smart cities and urban safety and privacy-related issues [20].

Then, with respect to existing cities, it is necessary to skip the issue of smart cities as new cities (see, for instance, [21], on India's smart cities, or several contributions on the case of Masdar City, in the UAE), and to link smart urbanism with regeneration, both as activities related to improving the quality of life and of the built environment in deprived areas, and also as initiatives for boosting the economic performances of productive areas, as well as central and creative districts. "Smart regeneration", a combination of words that has not succeeded in literature as smart urbanism did, has been referred to in several contributions that have dealt with the issue of regeneration and urban development; the way it has been analyzed and debated, however, has often been largely uncritical [22,23] or oriented towards the emergence of conflicts and constraints [24]. The second line of reasoning is, of course, much more interesting, and is able to provide a deeper insight into transformations in cities related to new technologies and infrastructures, or into the actual potentials for exploiting synergies between different spheres of interventions (as in the case of metabolism, governance, smart infrastructure and culture, whose synergies were explored by Allam and Newmann and by Allam et al. in the context of Port Luis, Mauritius; [25] and [26], respectively).

It does not seem, though, that a specificity of regeneration processes can be ascribed to them being - or not—smart. Regeneration initiatives, for instance, and especially when related to deprived areas, are strictly connected to public actors' decisions and, to a certain extent, funds, as is demonstrated by almost 30 years of EU Urban policy [27]. On the other hand, smart initiatives usually also involve other typologies of "smart actors" in different phases of the regeneration process, with private actors playing a greater role in promoting, funding and/or benefitting from such initiatives. Moreover, public actors are often given the role of gatekeepers of fuzzily defined public interests, while other actors intervene, transform, manage the process and its outcomes in cities that resemble test-beds [24,28,29]. What is interesting, however, is that those areas of the city that are interested in such initiatives are often labelled as smart and sustainable districts or neighborhoods, connecting almost naturally and uncritically two different ideas of development or regeneration.

The second issue is related to the concept of sustainable neighborhoods and eco-districts. When unfolding the smart and sustainable city paradigm, an aspect that certainly deserves investigation 
concerns the fact that the interest in specific areas within cities is often intended as a way to position the same city at the forefront of the debate concerning sustainability and energy transition. These episodes of change and innovation are generally referred to under the umbrella terms "sustainable neighborhoods" or "eco-districts"; two terms that cannot clearly be distinguished and that often overlap. Despite their exponential increase in number during the last two decades, in fact, their features are far from being homogeneous, with each model developing according to its own specific path. Furthermore, as previously mentioned, both the sustainability and the ecological virtues that are implied by such models are often seen as an additional outcome of a smart agenda, with aspects of urban development and regeneration (e.g.: governance, equity, culture, etc.) that are left out of the equation [18].

The aim of the research is, therefore, to focus on the neighborhood, a specific urban scale that has often been at the center of attention, so as to shed some light on the matter. In particular, the objective of the present study is to use the literature to reconstruct a conceptual framework through which to identify and investigate the concept of the eco-district that, together with the sustainable neighborhood one, is frequently cited. To achieve this, the paper reviews the concepts of sustainable neighborhood/ eco-districts in the literature, to then explore whether several indicators, emerging from the analysis of exemplary case studies of sustainable neighborhoods in Europe, can be used to clearly identify the characteristics of a sustainable approach at the district scale. However, it is not within the scope of this paper to define a set of indicators to measure eco-district and sustainable neighborhood experiences, but rather to identify the current strategies which determine the definition of a district/neighborhood as sustainable. Starting from these statements, the paper is structured as follows: following this introduction, a methodology section defines the conceptual framework and the steps of the analysis of the paradigms of sustainable neighborhoods and eco-districts and their role in current urban practices. Section 3 identifies the main aspects and actions that characterize the most relevant examples of European eco-districts discussed in literature. Then Section 4 connects the theoretical ways of understanding and approaching the concept of sustainable neighborhood/eco-districts, identified in the Introduction and Section 2.1, with the exemplary case studies finding in literature, in order to better investigate the actual correspondence between theoretical reflections and empirical evidence. Finally, Section 5 rounds off the contribution, presenting the authors' concluding remarks and bringing forward several future research perspectives, also concerning the actual potential for transferability of the presented European experiences.

\section{Methodology}

\subsection{Conceptual Framework and Steps of the Analysis}

When reflecting upon sustainability in neighborhoods, the first conundrum concerns the very meaning of the concept itself, as the latter is often defined in the literature through the use of a very broad array of elements and characteristics. In this light, there is a need to define more precisely what the object of analysis is, and to further unravel it in the light of the conceptual categories at stake.

First, it is important to focus on the actual meaning of district/neighborhood, as well as on the role they (may) play within the urban areas they are located into. As Choguill [30] (p. 42) underlines, "there is no population size specified in the definition, nor any universal civic function that a neighborhood is supposed to fulfil". At the same time, it seems limited to consider the neighborhood as only a sub-division of the urban area; neighbors and their social interactions play, in fact, a fundamental role in recognizing a place. Similarly, the relations between a part and the whole, i.e., between a specific district or neighborhood and the urban area it is located within, deserve attention, as only through their analysis is it possible to reflect on the actual impact of selected interventions in terms of upscaling, side-scaling and/or transferability [31,32].

In this sense, it has been recognized that the neighborhood level is the appropriate one for implementing sustainability principles in urban development. In fact, it represents a "meso" level of 
analysis and actions between city and buildings where several types of social networks and institutions are active, thus offering more opportunities for participation in collective decisions [33].

Some light should then be shed upon what is intended by "sustainable", i.e., how the various dimensions of sustainability concepts are approached by the literature dealing with sustainable urban transformations, sustainable neighborhoods/eco-districts, etc. Here, Choguill [30] provides a first subdivision between economic, social, technical and environmental sustainability, presenting the main aspects of each dimension. For their part, Luederitz et al. [34] go much further down the same path by producing a systematic review of the main guiding principles that characterize sustainable neighborhood interventions explored in the literature. As a result of their analysis, they produce a list of nine integrated principles for sustainable urban neighborhood development that may be of use when exploring the potentials and limits of existing European examples [34]:

1. Development of a harmoniously coupled human-environment system (promoting the protection of existing ecosystems, developing with the given landscape, historical background, socialeconomic-political situation, encouraging biodiversity and the production of local food);

2. Sustainable urban metabolism (considering comprehensive water management, a reduction of energy consumption promoting different renewable energy sources, developing a transition from energy consumer neighborhood to energy producer);

3. Environmentally benign building design using local and sustainable materials (together with the use of local, low embodied energy, high insulation performance and ecological materials, this principle considers also the reuse, renovation and recycling of existing structures and constant analysis of residents' behavior and behavioral change)

4. Catering for a livable and vibrant neighborhood (a mix of uses is encouraged, giving strong relevance to public spaces, as well as a mix of building typologies. Sustainable business opportunities should also be considered for avoiding gentrification and promoting mixed-income levels);

5. Provide compact development and integrated sustainable mobility (proposing a contiguous compact neighborhood in which primary services and daily needs are guaranteed, public transport is also strongly encouraged through a reduction of motorized transportation and streets are designed as public spaces);

6. Catering for resilient neighborhoods (ensuring an interactive and adaptive process);

7. Ensuring democratic governance and empowerment of neighborhood residents (promoting residents' engagement, different education facilities and workshops for knowledge exchange);

8. Satisfaction of human needs (integration of marginalized populations and mitigation of adverse impacts on disadvantaged groups);

9. Consideration of the neighborhood's impact on the wider environment (promoting the neighborhood as a showcase to spread sustainable measures to the broader city).

Bearing in mind the above, this analysis was carried out according to a sequence of steps. Firstly, this work starts from the analysis of the literature related to the sustainable paradigms at a district scale through the Scopus database, one of the largest and most important databases of scientific publications, using the keywords "eco district" OR "sustainable neighborhood" OR "sustainable district". Secondly, starting from the selected articles, the research restricted its attention to those papers that focus on the explanation of the actions and strategies developed by existing case studies known as examples of eco-districts and sustainable neighborhoods. Thirdly, the analysis considered only the projects characterized by the highest numbers of citations registered in the Scopus database in order to restrict the analysis only to the most exemplary cases. Finally, the investigation of the selected case studies is based on four main dimensions of sustainability (i.e., energy, socio-economic, mobility and urban design dimensions) in order to highlight commonalities and differences. The aforementioned steps are presented more in detail in the following subsections. 


\subsection{Selection of Eco-District Examples}

The literature on the issue of eco-district and sustainable neighborhood in Europe is quite vast, despite the recent proliferation (essentially, everything has been published since 2000) of these themes (Figure 1). The analysis of scientific databases such as Scopus shows us many articles in which the primary topic is the investigation of sustainable models of (energy) transition, both related to the experimental investigation of new theoretical models of transformation of parts of a city, and also to the analysis of existing case studies known to be examples of eco-districts or sustainable neighborhoods. With regard to the latter group, the analysis of the literature showed a predominance of examples from Northern or Western Europe, while examples from Southern Europe are rarely mentioned in literature and, often, only by authors from this geographical area. It is not so clear if these figures depend or not on the greater efficiency of these case studies compared to others, or on the presence in Northern Europe of more favorable institutional conditions [35]—or, prosaically, on the combination of a larger number of examples and a tendency to focus on certain areas to look for innovation-but, consequently, it is not surprising that Kyvelou et al. (2012) [36] define the sustainable neighborhood concept as a Northern European model.

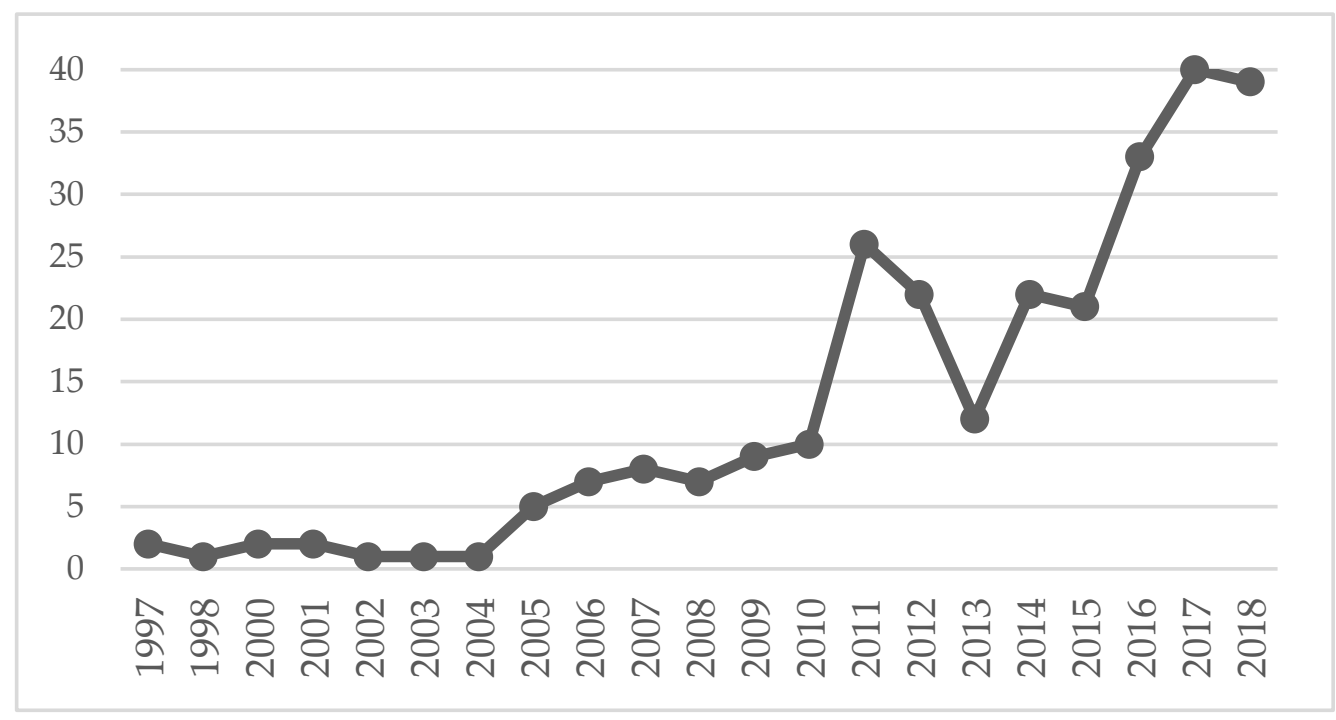

Figure 1. The number of articles in the context of eco-district and sustainable neighborhoods indexed in the Scopus database.

Medved $(2016,2018)[37,38]$ gave an extensive list of the most cited leading examples of sustainable neighborhoods (from Northern and Western Europe). The search for scientific documents in the Scopus database using the keywords "eco district" OR "sustainable neighborhood" OR "sustainable district", allowed the integration of Medved's research with new case studies reported in the literature, also considering examples from Southern Europe. Table 1 reports the list of sustainable neighborhoods based on the existing literature, identifying the city, the project name and the authors that reviewed or cited each eco-district. Only cases with more than one citation in Scopus, those in capital letters in the table, were then further investigated in order to clarify their specific features (Table 2). It has to be noted that all of the selected examples refer to recently completed projects. 
Table 1. Eco-district examples.

\begin{tabular}{|c|c|c|}
\hline City & Projects Name & Authors \\
\hline LINZ (Austria) & SolarCity & $\begin{array}{l}\text { Medved, 2016, } 2017 \text { [37,39]; } \\
\text { Schroepfer, } 2008[40]\end{array}$ \\
\hline COPENHAGEN (Denmark) & Vesterbro & $\begin{array}{l}\text { Marique, } 2011 \text { [41]; Cucca, } 2017 \text { [42] } \\
\text { Medved, } 2016 \text { [37] }\end{array}$ \\
\hline Kalundborg (Denmark) & Kalundborg & Caiati, $2016[43]$ \\
\hline Helsinki (Finland) & Viikki & Medved, 2016 [37] \\
\hline BORDEAUX (France) & Ginko & Flurin, 2017 [44]; Tozzi, 2014 [45] \\
\hline Paris (France) & $\begin{array}{l}\text { Gare de Rungis (13th), } \\
\text { Clichy-Batignolles (17th), Pajol } \\
\text { (18th), Frequel-Fontarabie (20th), } \\
\text { Boucicaut (15th) and Claude } \\
\text { Bernard (19th) }\end{array}$ & Machline, 2016 [46] \\
\hline Saint Ouen (France) & Docks de Saint Ouen & Flurin, 2017 [44] \\
\hline FREIBURG (Germany) & Riesfield & $\begin{array}{l}\text { Zaręba, } 2017 \text { [47]; Medved, 2016, } \\
2017 \text { [37,39]; Hagen, } 2017 \text { [48] }\end{array}$ \\
\hline FREIBURG (Germany) & Vauban & $\begin{array}{l}\text { Zareba, } 2017 \text { [47]; Medved, 2016, 2017, } \\
2018 \text { [37-39]; Hagen, } 2017 \text { [48]; } \\
\text { Marique, } 2011 \text { [41]; Kasioumi, E., } \\
2011 \text { [49]; Schroepfer, } 2008 \text { [40] }\end{array}$ \\
\hline HANOVER (Germany) & Kronsberg & Marique, 2011 [41]; Medved, 2016 [37] \\
\hline Ostfildern (Germany) & Scharnhauser Park & Medved, 2016 [37] \\
\hline Tubingen (Germany) & Französisches Viertel—Südstadt & Medved, 2016 [37] \\
\hline Cloughjordan (Ireland) & Cloughjordan Eco-village & Zaręba, 2017 [47] \\
\hline Amsterdam (Netherlands) & GWL Terrein & Medved, 2016 [37] \\
\hline Amsterdam (Netherlands) & Haven-Stad (Port-City) & Bossuyt, 2017 [39] \\
\hline CULEMBORG (Netherlands) & Eva-Lanxmeer & Marique, 2011 [41]; Medved, 2016 [37] \\
\hline Utrecht (Netherlands) & Leidsche Rijn & Medved, 2016 [37] \\
\hline Barcelona (Spain) & Lliçà d'Amunt & Vall-Casas, 2016 [50] \\
\hline BARCELONA (Spain) & Trinitat Nova & Flurin, 2017 [44]; Medved, 2016 [37] \\
\hline Barcelona (Spain) & Vallbona & Farreny, 2011 [51] \\
\hline MALMO (Sweden) & Augustenborg & Marique, 2011 [41]; Medved, 2016 [37] \\
\hline MALMO (Sweden) & bo01 & $\begin{array}{l}\text { Flurin, } 2017 \text { [44]; Zaręba, } 2017 \text { [47]; } \\
\text { Medved, 2016, 2017, } 2018 \text { [37-39]; } \\
\text { Fitzgerald, } 2016 \text { [52]; } \\
\text { Marique, } 2011 \text { [41] }\end{array}$ \\
\hline STOCKHOLM (Sweden) & Hammarby Sjostad & $\begin{array}{l}\text { Bossuyt, } 2017 \text { [53]; Marique, } 2011 \text { [41]; } \\
\text { Kasioumi, E., } 2011 \text { [49] }\end{array}$ \\
\hline LONDON (UK) & Bed Zed & $\begin{array}{l}\text { Machline, } 2016 \text { [46]; Marique, } \\
2011 \text { [41]; Medved, 2016, } 2018 \text { [37,38] }\end{array}$ \\
\hline LONDON (UK) & Royal Seaport & Bossuyt, 2017 [53]; Medved, 2016 [37] \\
\hline LONDON (UK) & Greenwich Millennium Village & Medved, 2016, $2017[37,39]$ \\
\hline
\end{tabular}

\section{Results}

As mentioned in the Introduction, the literature gives a very broad range of concepts to define the models of the so-called eco-district or sustainable neighborhood. To give a more comprehensive view of the meaning of these models at district scale or, at least, to verify them through empirical evidence, this contribution tries to find more information on the most cited exemplary case studies of sustainable neighborhoods and, in addition, to identify some indicators as a starting point for a more detailed analysis.

To start, the information for each selected project was collected using several sources, such as scientific articles, dedicated web sites, local press, and so on. Table 2 shows the information collected for each project, clustered into four main dimensions: 1. Energy and natural resources, 2. Socio-economic dimension, 3. Mobility dimension, 4. Urban design dimension. Each action in Table 2 reports a code that refers to the indicators identified later in Figures 2-5. The four dimensions, instead, have been recognized as the pillars of urban sustainability, focusing on desirable neighborhoods 
characteristics, green policies, sustainable features and design elements [37]. In addition, these pillars are strictly in line with the "Sustainable Development Goals" adopted by all United Nations Member States [54] and, more generally, with the three dimensions of sustainability (social, economic and environmental dimensions). Moreover, these dimensions are broad enough in their scope to be used to sift through the collected information and, also, they shed some light on the prominent role of physical and technological actions which characterize the current exemplary sustainable neighborhoods. In fact, the first dimension (Energy (and natural resources)) highlights the major role of energetic aspects, in contrast to environmental ones, for its relationship with everyday activities that strongly contribute to achieving environmental benefits. This pillar considers, among the others, energy systems, building materials and energetic performances, water and waste sustainable solutions. However, some actions that are aimed at improving essentially environmental-natural conditions (such as increasing biodiversity or flood protection) are also included. The second dimension (Socio-economic) provides, at the same time, information regarding residents' engagement and job opportunities during and after the project, the types of investors, the decision orientation (top-down/bottom-up) and the level of neighbor diversity. The third dimension (Mobility) represents a fundamental aspect in all eco-districts' actions, due to the twofold advantage produced. On one hand, it allows the decrease of negative effects raised by the use of private cars thanks to a strong increase and efficiency of public or alternative means of transport. On the other hand, it proposes streets as a sharing place for pedestrians and bikers. The fourth dimension (Urban design) considers the physical characteristics of the neighborhood, both in terms of private and public spaces. This dimension is particularly important, as the majority of existing eco-districts is developed in brownfield areas or underdeveloped parts of the city.

The four dimensions fit well with the exemplary European case studies analyzed, both for the Northern-Western eco-districts and for the Southern ones. However, a broader collection of case studies, in particular, those of other countries, could potentially change the perspective of the analysis by giving more importance to other dimensions with different strategies and actions. 
Table 2. Description of the eco-districts based on the four sustainability dimensions.

\begin{tabular}{|c|c|c|c|c|}
\hline & Energy and Natural Resources Dimension & Socio-Economic Dimension & Mobility Dimension & Urban Design Dimension \\
\hline $\begin{array}{l}\text { Solar City } \\
\text { LINZ } \\
\text { (Austria) }\end{array}$ & $\begin{array}{l}\text { - at least one-third of the hot water is generated by } \\
\text { - } \text { solar energy [E7]*1 } \\
\text { two-thirds of the neighborhood are covered by } \\
\text { district heating (CHP) [E8] } \\
\text { water management (wastewater will be disposed } \\
\text { and treated in a separation system) [E2] } \\
\text { - part of the wastewater used as fertilizer in } \\
\text { agriculture [E4] } \\
\text { rainwater has special channels or can be fed into the } \\
\text { raceway in north of the SolarCity [E3] } \\
\text { high level of thermal insulation [E5] } \\
\text { - } 3 \text { passive houses [E9] } \\
\text { ecological components of the building [E6] }\end{array}$ & $\begin{array}{ll}\text { - } & \text { Resident participation [SE1]*2 } \\
\text { - } & \text { A m marketing district management office [SE2] } \\
& \text { such as quality of life and environment [SE3] }\end{array}$ & $\begin{array}{ll}\text { - } & \text { new tramway routes (max } \\
\text { walking distance } 300 \mathrm{~m} \text { to } \\
\text { apartments) [M1]*3 } \\
\text { - } \quad \text { railway connection [M2] } \\
\text { - } \quad \text { bus line extended [M3] } \\
\text { path network for pedestrians and } \\
\text { bikers [M4] } \\
\text { - nearly car free area and } \\
\text { underground parking lots [M6] } \\
\text { new bypass road [M7] }\end{array}$ & $\begin{array}{l}\text { - mix of functions: } 1300 \text { apartments [UD1] }{ }^{* 4}+ \\
\text { central infrastructure (local shops, socio-cultural } \\
\text { facilities, school center, kindergarten, pastoral } \\
\text { center, sports park) [UD8] } \\
\text { building with 2-4 stories high [UD3] } \\
\text { - } \quad \text { green space (60\%) [UD5] } \\
\text { large recreational facilities (lake, bicycle paths, } \\
\text { hiking trails) [UD6] } \\
\text { compact constructions and south orientation } \\
\text { [UD10] Inter-entrepreneurial activities (project } \\
\text { supervisory board as consulting organ during } \\
\text { the planning phase, central office for the } \\
\text { operational process, advisory council, project } \\
\text { contract,....) [UD4] }\end{array}$ \\
\hline $\begin{array}{l}\text { Vesterbo } \\
\text { COPENHAGEN } \\
\text { (Denmark) }\end{array}$ & $\begin{array}{l}12 \text { different water waste collectors [E3] } \\
\text { - } \quad \text { retrofitting of } 280 \text { dwellings [E1] }\end{array}$ & $\begin{array}{l}\text { - } \quad \text { top-down" approach [SE4] } \\
\text { - } \quad \text { 95\%munication centers [SE2] } \\
\text { - } \quad \text { subsidies for highey [SE6] } \\
\\
\text { limited European funds) [SE7] }\end{array}$ & $\begin{array}{l}\text { - new tramway routes (before } \\
\text { building district) [M1] }\end{array}$ & $\begin{array}{ll}\text { - } & \text { mix of functions [UD1] } \\
\text { - } & \text { very dense district [UD7] }\end{array}$ \\
\hline $\begin{array}{l}\text { Ginko } \\
\text { BORDEAUX } \\
\text { (France) }\end{array}$ & $\begin{array}{l}\text { - exemplary project in environmental and } \\
\text { architectural matters (HQE approach, carbon } \\
\text { footprint across the ZAC, limitation of energy and } \\
\text { water consumption, etc.) [E11] } \\
\text { - materials that comply with environmental } \\
\text { standards [E6] } \\
\text { - stock of trees [E16] }\end{array}$ & $\begin{array}{l}\text { - a functional and social mix ( } 33 \% \text { of social rental } \\
\text { housing; } 20 \% \text { of assisted access; } 22 \% \text { of social and } \\
\text { moderate membership, } 45 \% \text { of free accession, ...) } \\
\text { [SE8] } \\
\text { creation of } 2000 \text { jobs [SE9] } \\
\text { - associative, cultural and educational centers [SE2] }\end{array}$ & $\begin{array}{l}\text { - Tramway: Line C creation and } \\
\text { extension (becoming a site } \\
\text { integrated with the rest of the } \\
\text { city) [M1] } \\
\text { infrastructure service (ring road } \\
\text { and A10 connecting Bordeaux to } \\
\text { Paris) [M7] }\end{array}$ & $\begin{array}{l}\text { - } \text { remarkable landscape qualities (enhancement of } \\
\text { the banks of the lake, development of an } \\
\text { ecological garden walk, ...) [UD9] } \\
\text { - diversity of building design [UD2] } \\
\text { - } \quad 40 \% \text { green space (including a } 4.5 \text { ha park) [UD5] } \\
\text { - } 300,000 \mathrm{~m}^{2} \text { of built-up areas divided between } \\
\text { housing, economic activities, equipment } \\
\quad+29,000 \mathrm{~m}^{2} \text { shopping center, composed of } \\
\text { medium-sized surfaces, shops, and local shops } \\
\text { articulated around a pedestrian public } \\
\text { square [UD1] }\end{array}$ \\
\hline $\begin{array}{l}\text { Riesfield } \\
\text { FREIBURG } \\
\text { (Germany) }\end{array}$ & $\begin{array}{l}\text { - new buildings with high standards of thermal } \\
\text { insulation [E5] } \\
\text { - heating system based on solar energy [E7] and } \\
\text { woodchips [E14] } \\
\text { - heat and power plants [E8] } \\
\text { a systematic water supply plan [E2] }\end{array}$ & $\begin{array}{l}\text { - built by more than } 120 \text { private builders and investors } \\
\text { [SE11] } \\
\text { civic engagement and active cooperation in the } \\
\text { district [SE1] }\end{array}$ & $\begin{array}{l}\text { - } 4 \text { min width play streets, used as } \\
\text { common community space, giving } \\
\text { priority to pedestrians) [M4] } \\
\text { new tram stops within a } \\
\text { 400-maximum distance from } \\
\text { every single household [M1] } \\
\text { - parking ratio less than } 0.5 \text { per } \\
\text { house unit [M6] } \\
\text { - parking-free residential streets } \\
\text { and car-free zones [M5] }\end{array}$ & $\begin{array}{ll} & \text { mix-use eco-suburbs [UD1] } \\
\text { - } & \text { 3-5 story buildings [UD3] } \\
\text { - } & \text { 250-hensity [UD7] } \\
\text { use as a local ruecreational area [UD6] } \\
\text { - } \\
\text { great importance to green spaces, play areas and } \\
\text { open spaces, as well as cycle paths and } \\
\text { pedestrianized streets [UD5] }\end{array}$ \\
\hline
\end{tabular}


Table 2. Cont

\begin{tabular}{|c|c|c|c|c|}
\hline & Energy and Natural Resources Dimension & Socio-Economic Dimension & Mobility Dimension & Urban Design Dimension \\
\hline $\begin{array}{l}\text { Vauban } \\
\text { FREIBURG } \\
\text { (Germany) }\end{array}$ & $\begin{array}{l}\text { - new buildings with high standards of thermal } \\
\text { insulation [E5] } \\
\text { heating system is based on solar energy [E7] and } \\
\text { woodchips [E14] } \\
\text { - Low-energy building is mandatory in this district } \\
\text { and around } 170 \text { units have been built as "passive" } \\
\text { houses and a further 70 as energy-plus homes [E9] } \\
\text { - Vegetation-covered "green" roofs store } \\
\text { rainwater [E10], which is collected [E3] and re-used } \\
\text { in the district [E4] } \\
\text { The former stock of trees has been largely } \\
\text { preserved [E16] }\end{array}$ & & $\begin{array}{l}\text { - new tram line (an increase of } \\
\text { frequencies, extension of city's } \\
\text { tram system) [M1] } \\
4 \mathrm{~m} \text { in width play streets, used as } \\
\text { common community space, giving } \\
\text { priority to pedestrians) [M4] } \\
\text { - } \quad \text { parking ratio less than 0.5 per } \\
\text { house unit [M6] } \\
\text { parking-free residential streets } \\
\text { and car-free zones [M5] }\end{array}$ & $\begin{array}{l}\text { - } \quad \text { mix-use eco-suburbs [UD1] } \\
\text { - } \quad \text { with 3-5 story buildings [UD3] } \\
\text { - } \quad \text { An infrastity (in Vauban } 122 \text { persons/ha) [UD7] } \\
\text { (schools, nursery sincorporating different, youth facilities, cervices } \\
\text { meeting places, a marketplace, as well as leisure } \\
\text { and play areas) were built in parallel with the } \\
\text { private development [UD8] }\end{array}$ \\
\hline $\begin{array}{l}\text { Kronsberg } \\
\text { HANOVER } \\
\text { (Germany) }\end{array}$ & $\begin{array}{l}\text { - quality controls were decided, planned and } \\
\text { formalized early in the process and set with very } \\
\text { precise and detailed specifications [E11] }\end{array}$ & $\begin{array}{l}\text { - } \quad \text { top-down" approach [SE4] } \\
\text { - comilt for the 2000 World Exposition [SE12] } \\
\text { - genmeral plation centerined: a precise tool was used to } \\
\text { gather specific objectives and requirements } \\
\text { applicable to private developers, land buyers and } \\
\text { future inhabitants [SE13] }\end{array}$ & & $\begin{array}{l}\text { - } 6000 \text { dwellings as well as shops and offices on } \\
150 \text { hectares [UD1] } \\
\text { avoiding long turnaround times, several stages } \\
\text { (operational and financial arrangements, } \\
\text { incidences evaluation, etc.) were conducted } \\
\text { simultaneously [UD4] }\end{array}$ \\
\hline $\begin{array}{l}\text { Eva-Lanxmeer } \\
\text { CULEMBORG } \\
\text { (Netherlands) }\end{array}$ & $\begin{array}{l}\text { - } \quad \text { self-sufficient neighborhood [E18] } \\
\text { food production [E17] }\end{array}$ & $\begin{array}{l}\text {-bottom-up" approach: citizens involved in the } \\
\text { development of their own districts [SE5] } \\
\text { constant involvement of the inhabitants (also, } \\
\text { inhabitants spend a few hours each month to } \\
\text { maintain public spaces) [SE1] } \\
\text { very strong local identity, sense of community and } \\
\text { community cohesion [SE10] }\end{array}$ & & \\
\hline $\begin{array}{l}\text { Trinitat Nova } \\
\text { BARCELONA } \\
\text { (Spain) }\end{array}$ & $\begin{array}{l}\text { - different options for heat generation (thermal solar } \\
\text { energy [E7], co-generation [E8] and heat pumps } \\
\text { [E15]) and distribution supply (totally centralized } \\
\text { system, partially centralized with separated storage } \\
\text { in buildings and totally independent systems) and } \\
\text { centralized co-generation system with } \\
\text { collective management } \\
\text { - wide range of passive features (such as } \\
\text { insulation) [E5] } \\
\text { infiltration and recollection of rainwater, water } \\
\text { recycling and re-use [E2] [E3] [E4] } \\
\text { a management plan for demolition and construction } \\
\text { waste [E12] }\end{array}$ & 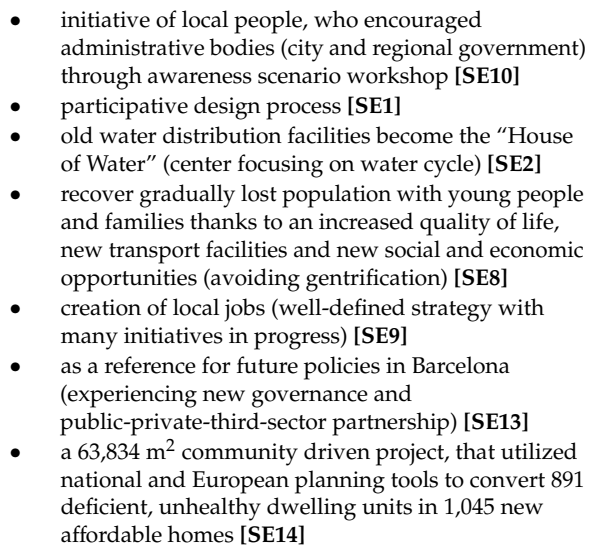 & $\begin{array}{l}\text { - light rail route connects the area to } \\
\text { the northern neighborhoods and } \\
\text { the existing underground will be } \\
\text { connected to the } \\
\text { neighborhood [M2] } \\
\text { new cycle route that connects } \\
\text { existing and planned Barcelona } \\
\text { cycle network [M4] } \\
\text { four semi-underground car parks } \\
\text { on the periphery (avoiding car } \\
\text { penetration in the } \\
\text { neighborhood) [M5] }\end{array}$ & $\begin{array}{l}\text { - mix of uses (housing units with shopping and } \\
\text { facilities on the ground floor) [UD1] } \\
\text { - } \quad \text { four-to-six-story housing units [UD3] } \\
\text { multidisciplinary technical team ("Plan } \\
\text { Comunitario") [UD4] }\end{array}$ \\
\hline
\end{tabular}


Table 2. Cont

\begin{tabular}{|c|c|c|c|c|}
\hline & Energy and Natural Resources Dimension & Socio-Economic Dimension & Mobility Dimension & Urban Design Dimension \\
\hline $\begin{array}{l}\text { Augustenborg } \\
\text { MALMO } \\
\text { (Sweden) }\end{array}$ & $\begin{array}{l}\text { - } 15 \text { centers for waste collection, reuse, recycling and } \\
\text { composting (recycling over } 50 \% \text { of all neighborhood } \\
\text { waste by 2009 while working towards a target of } \\
90 \% \text { ) [E12] } \\
400 \mathrm{~m}^{2} \text { solar thermal collectors (many removed after } \\
\text { few years, because they were out of service), } 100 \mathrm{~m}^{2} \\
\text { photovoltaic cells [E7] and ground source heat pump } \\
\text { [E15] feed directly into the district heating system } \\
\text { (heat and hot water consumption decreased by } 25 \% \\
\text { by 2009, and the carbon emissions more than } 20 \% \text { ) } \\
\text { green roof vegetation [E10] and an integrated open } \\
\text { stormwater management system to solve } \\
\text { recurrent flooding } \\
\text { increased biodiversity by } 50 \% \text { by creating natural } \\
\text { habitats [E13] } \\
\text { energy efficiency of } 1,600 \text { public rental apartments } \\
\text { (89\% of the total housing stock in the area) [E1] }\end{array}$ & $\begin{array}{l}\text { - "top-down" approach [SE4] } \\
\text { Residents' needs, expectations and perspectives were } \\
\text { taken into account throughout the whole process of } \\
\text { urban renewal [SE1] } \\
\text { development of community activities and services } \\
\text { (educational projects, social enterprises, meeting } \\
\text { points for discussion) with spaces for residents to } \\
\text { meet and share ideas [SE2] } \\
\text { Funding from local, national and EU levels, as well } \\
\text { as from the MKB: US } \$ 28 \text { million was invested in the } \\
\text { area, half by the MKB to improve housing stock; } \\
\text { US\$3.4 million from the LIP initiative, US } \$ 840,000 \\
\text { from EU funding in the LIFE-programme; US\$ } 10 \\
\text { million from local government [SE6] [SE7] }\end{array}$ & $\begin{array}{ll}- & \text { new tramway routes [M1] } \\
- & \text { car-pooling scheme [M8] }\end{array}$ & $\begin{array}{l}\text { - the creation and shaping of public space into } \\
\text { parks, allotments, play areas for children, hubs } \\
\text { for increased biodiversity [UD5] }\end{array}$ \\
\hline $\begin{array}{l}\text { bo01 } \\
\text { MALMO } \\
\text { (Sweden) }\end{array}$ & $\begin{array}{l}\text { - local renewable resources (up to } 100 \% \text { ) [E18]: } \\
\text { community heat pump installation from natural } \\
\text { underground reservoir [E15] } \\
\text { - water waste (up to } 12 \text { different kinds of waste } \\
\text { collected) [E3] } \\
\text { - ENVAC sustainable waste collection system is now } \\
\text { used in other European cities [E12] } \\
\text { - } \quad \text { Rainwater drainage system, used in public space } \\
\text { (waterfalls, gutters, artificial ponds for storage and to } \\
\text { purify rainwater) [E4] } \\
\text { - recycled water, raw materials and waste are } \\
\text { reused [E17] } \\
\text { - high environmental quality and biodiversity [E13] }\end{array}$ & $\begin{array}{l}\text { - "top-down" approach [SE4] } \\
\text { initiated and developed in the scope of a worldwide } \\
\text { event [SE12] } \\
\text { - public subsidies: } 16 \text { million } € \text { from the city and } 32 \\
\text { from the state [SE6] } \\
\text { masterplan focused on stakeholders' coordination } \\
\text { with the "Vision } 2000 \text { ", to provoke discussions with } \\
\text { the public, and the "Quality program", a } \\
\text { participatory planning toolbox [SE13] }\end{array}$ & & $\begin{array}{l}\text { - New tools to accompany the developments (ex.: } \\
\text { a quality charter to respect at least } 10 \text { of the } 35 \\
\text { environmental points proposed to guarantee } \\
\text { urban density, architectural diversity together } \\
\text { with high environmental quality and } \\
\text { biodiversity). However, it did not provide any } \\
\text { sanctions in the case of non-adherence [UD4] }\end{array}$ \\
\hline $\begin{array}{l}\text { Hammarby } \\
\text { Sjostad } \\
\text { STOCKHOLM } \\
\text { (Sweden) }\end{array}$ & $\begin{array}{l}\text { - ENVAC sustainable waste collection system is now } \\
\text { used in other European cities [E12] } \\
\text { Water efficiency measures such as stormwater } \\
\text { management (smaller pipe dimensions also reduce } \\
\text { the cost of 'hard' infrastructure) [E3] }\end{array}$ & $\begin{array}{l}\text { - "top-down" approach [SE4] } \\
\text { initiated and developed in the scope of a worldwide } \\
\text { event [SE12] }\end{array}$ & - tramway routes [M1] & $\begin{array}{l}\text { - The low impact design of the stormwater } \\
\text { management system also led to attractive public } \\
\text { green spaces [UD5] }\end{array}$ \\
\hline
\end{tabular}


Table 2. Cont.

\begin{tabular}{|c|c|c|c|c|}
\hline & Energy and Natural Resources Dimension & Socio-Economic Dimension & Mobility Dimension & Urban Design Dimension \\
\hline $\begin{array}{l}\text { Royal Seaport } \\
\text { STOCKHOLM } \\
\text { (Sweden) }\end{array}$ & $\begin{array}{l}\text { - Local soil remediation and on-site re-use of } \\
\text { excavated material reduces the need for } \\
\text { transport [E17] } \\
\text { The buildings are close-to-zero energy buildings } \\
\text { (well-insulated and airtight, have energy-efficient } \\
\text { installations) [E3] } \\
\text { local production of energy, such as photovoltaics on } \\
\text { the roof, reduces climate impact and saves } \\
\text { resources [E7] } \\
\text { a waste disposal unit, vacuum, waste collection } \\
\text { system, recycling rooms, a mobile re-use station and } \\
\text { a hazardous waste station [E12] } \\
\text { considering important ecosystem services, such as } \\
\text { flood protection, temperature regulation, recreation, } \\
\text { greater biodiversity and strengthened dispersal } \\
\text { patterns for key species [E13] }\end{array}$ & $\begin{array}{l}\text { - Residents, employees, developers, politicians, } \\
\text { researchers, municipalities and authorities are } \\
\text { engaged in ongoing dialogue [SE13] } \\
\text { - 30,000 new jobs [SE9] }\end{array}$ & $\begin{array}{l}\text { - } \\
\text { street space gives priority to } \\
\text { pedestrians, cyclists and public } \\
\text { transport and paths for walking } \\
\text { and cycling were expanded [M4] } \\
\text { - } \quad \text { Public transport is based on } \\
\text { underground and buses [M3] } \\
\text { - Easy access to charging points will } \\
\text { promote the use of electric } \\
\text { vehicles [M9] }\end{array}$ & $\begin{array}{l}\text { - a mix of housing, businesses, retail and } \\
\text { services [UD1] }\end{array}$ \\
\hline $\begin{array}{l}\text { BedZed } \\
\text { LONDON } \\
\text { (UK) }\end{array}$ & $\begin{array}{l}\text { - } \quad \text { anticipatory experiences of energy transition in } \\
\text { which materials played a very important role [E6] } \\
\text { most bulk materials and labor were sourced within a } \\
\text { 50-mile radius of the site [E17] } \\
\text { - on-site water treatment plant [E2] } \\
\text { - woodchip fueled combined heat and power } \\
\text { plant [E14] [E8] } \\
\text { - } \text { Roof garden [E10] }\end{array}$ & $\begin{array}{l}\text { - the sustainable neighborhood is initiated and } \\
\text { managed by a private developer [SE11] }\end{array}$ & - car-sharing and car-pooling [M8] & \\
\hline $\begin{array}{l}\text { Greenwich } \\
\text { Millennium } \\
\text { Village } \\
\text { LONDON } \\
\text { (UK) }\end{array}$ & & $\begin{array}{l}\text { - Millennium Communities Programme (launched by } \\
\text { English Partnerships alongside the Department for } \\
\text { Communities and Local Government) [SE13] } \\
\text { - } 1400 \text { dwellings with 20\% of affordable } \\
\text { housing [SE14] }\end{array}$ & $\begin{array}{l}\text { - } \quad \text { 2-lane dedicated busway [M3] } \\
\text { Limited car traffic (car uses } \\
\text { significantly lower than in } \\
\text { surrounding areas) with car-free } \\
\text { and priority to cyclists and } \\
\text { pedestrians [M5] } \\
\text { - Network of cycle and pedestrian } \\
\text { routes (with secure bicycle storage } \\
\text { facilities, several covered and } \\
\text { whether-protective facilities) [M4] } \\
\text { - Car-sharing vehicles (but } \\
\text { limited) [M8] } \\
\text { - Monitoring of transit stops, cycle } \\
\text { routes and pedestrian areas [M10] } \\
\text { Parking available only for } 80 \% \text { of } \\
\text { units and residents who want a } \\
\text { parking (not private) must pay for } \\
\text { the "right to park" [M6] }\end{array}$ & $\begin{array}{l}\text { - Mix of uses [UD1] } \\
\text { - High density residential buildings [UD7] } \\
\text { different type of buildings depending on the } \\
\text { area [UD2] } \\
\text { Ecology park (0.2 square kilometers) with } 2 \text { lakes } \\
\text { and a thriving wildlife population and garden } \\
\text { squares through-out the residential } \\
\text { areas [UD5] [UD9] } \\
\text { Small grocery store, pharmacy and several cafes } \\
\text { (in the village square) and 4500 square meters of } \\
\text { commercial space along with community } \\
\text { facilities (school and health center) [UD8] }\end{array}$ \\
\hline
\end{tabular}

$* 1[\mathrm{E} 1, \mathrm{E} 2, \ldots, \mathrm{E} 18]$ refer to the indicators code of Figure $2 ; * 2[\mathrm{SE} 1, \mathrm{SE} 2, \ldots, \mathrm{SE} 14]$ refer to the indicators code of Figure $3 ; * 3$ [M1, M2, . , M10] refer to the indicators code of Figure 4 ; $* 4[\mathrm{UD} 1, \mathrm{UD} 2, \ldots, \mathrm{UD} 9]$ refer to the indicators code of Figure 5 . 


\section{Discussion}

\subsection{Reflections on Eco-District Models}

Through the analysis of the characteristics of each project, it was possible to develop some empirical insights in relation to sustainability in neighborhoods and its related models. In this sense, for each one of the considered sustainability dimensions, several sub-dimensions have been defined that better specify the contents. It has to be noted that the sub-dimensions were defined based on an inductive method in order to classify and to cluster all the specific actions of each case study in unique identifications. The results of this analysis are represented in radar graphs, where the axes are the sub-dimensions identified, whereas the data points show the number of cases presenting specific actions and interventions under the considered categories (Figures 2-5). A specific code was assigned in order to ease the connection among those categories and the single actions adopted by the case studies reported in Table 2 . These values, rather than representing a definitive number, make it possible to understand which characteristics were considered more relevant in developing an eco-district (or sustainable neighborhood).

In the selected experiences, energy aspects have certainly been identified as a priority in developing an eco-district. A transition from non-renewable energies to low environmental impact technologies, such as PV systems, heat pumps or CHP, was widely occurring. It is not surprising that this dimension contains the largest number of indicators (Figure 2). An interesting aspect is that the retrofit was not widely proliferated, precisely because many of these projects were in areas with different land-use or that had been under-developed in the past. Instead, the adoption of high-performance insulation systems and the development of the first attempts to develop passive houses and close to zero energy buildings were both more common. Apart from that, strong importance is given to water and waste. Different actions and technologies are applied to their collection, separation and re-use, showing the strong efforts to limit their environmental impact and waste. The actions undertaken not only have a direct effect on the districts, such as the reduction of flooding risks, but also have positive implications at a wider scale, such as the reduction of water consumption and the increasing of municipal waste management. However, less attention has been given to natural resources such as ecosystem and biodiversity protection, due to the stronger prominence in the development of such eco-districts of technological and energetic aspects for acquiring environmental benefits.

If actions related to the energy dimension go in the same direction for all case studies analyzed, something different happens for the socio-economic aspects (Figure 3). Some projects, in fact, adopt what is described as a bottom-up approach, others (the majority) a top-down approach. Some case studies were mainly financed by private actors, others through public investment, EU subsidies and mega-events. In general, as already stressed elsewhere [35], the success of the projects, both bottom-up and top-down, seems to come from a widespread communication, participation and engagement of the population, through the creation of meeting places and the diffusion of community activities, as well as the creation of private-public partnerships and strong stakeholder coordination and engagement (see SE13 in Figure 2). Successful projects have also resulted in the creation of local jobs. Instead, the promotion of social mixing, also with previous inhabitants, has still not been widely considered, generating gentrification phenomena. The increasing values of new housing (and of the perceived quality of life) attract inhabitants with higher income levels and cause the displacement of lower-income inhabitants.

As for the energy aspects, also for the mobility ones (Figure 4), actions were similar among the different projects. The aim is to discourage the use of private cars through the implementation of public mobility services (in particular new tramway routes). In addition, the disincentive of private cars is encouraged by the proliferation of car-free areas and by a reduction in the number of parking lots, often isolated in the district borders. In many cases, these actions are combined with an increase of streets reserved for pedestrians and bikers. Cars are promoted only when electric or combined with carpooling and car-sharing initiatives. 


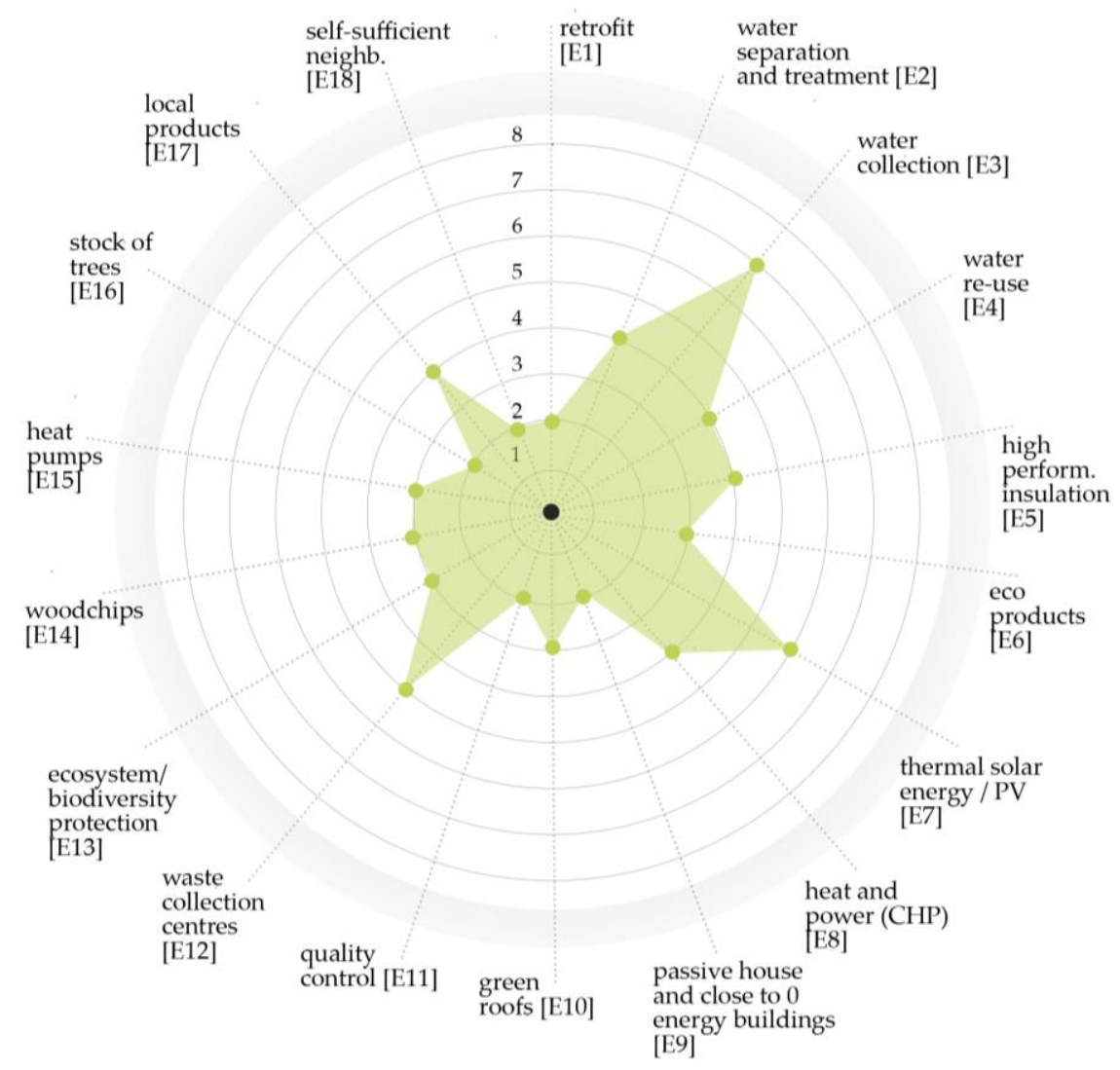

Figure 2. Presence of elements related to the energy dimension in the considered case studies.

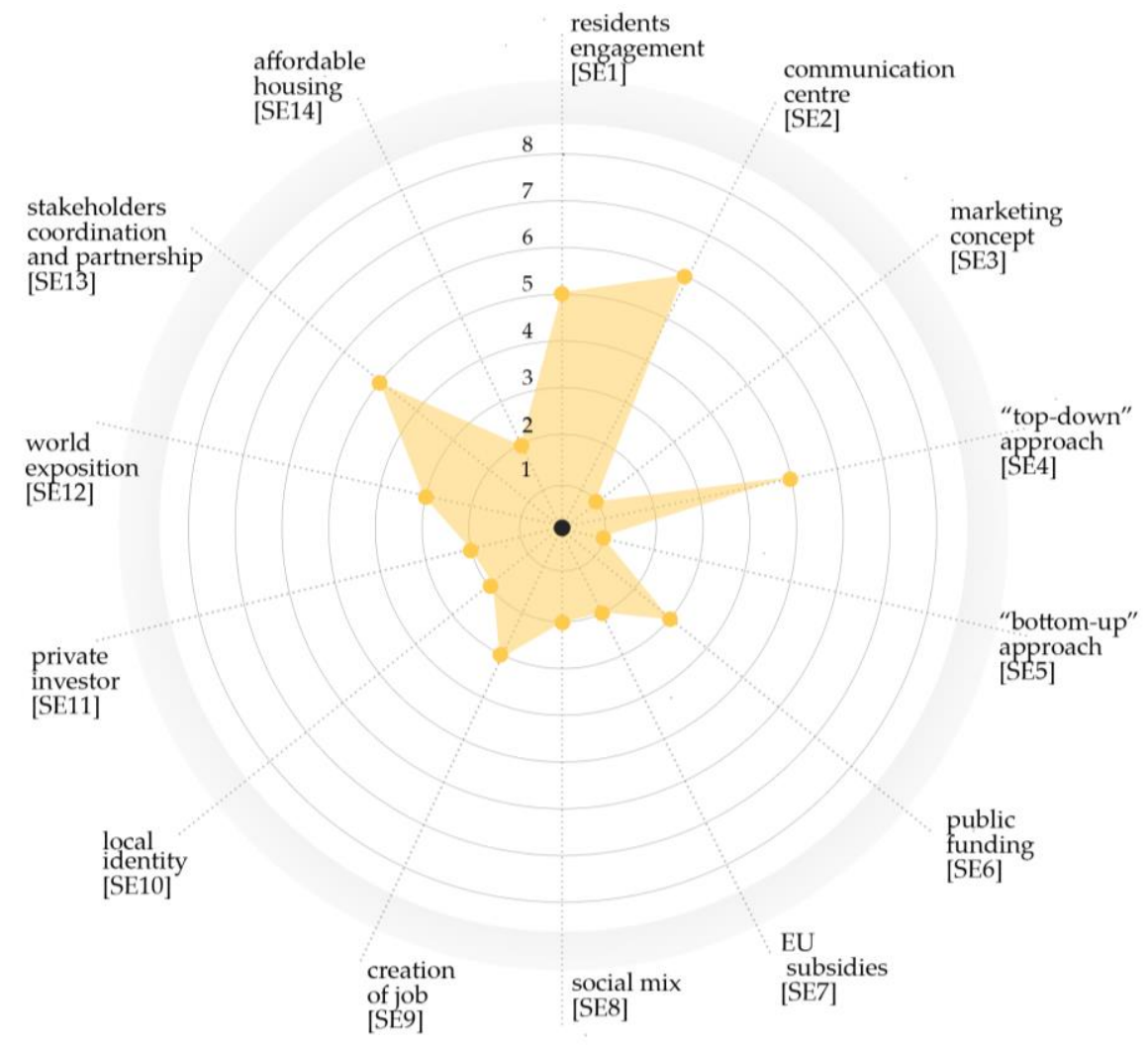

Figure 3. Presence of elements related to the socio-economic dimension based on the considered case studies. 


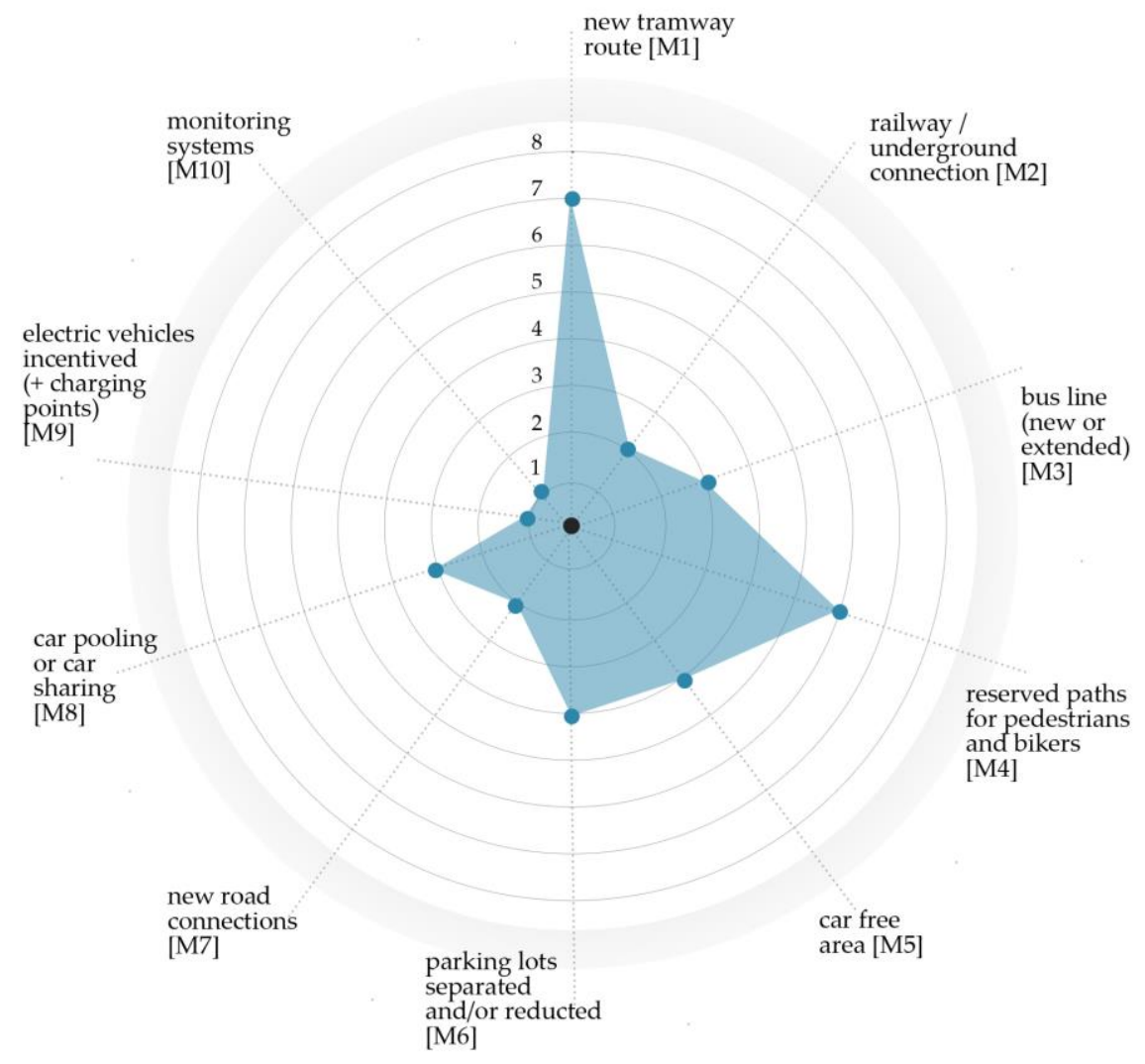

Figure 4. Presence of elements related to the mobility dimension based on the considered case studies.

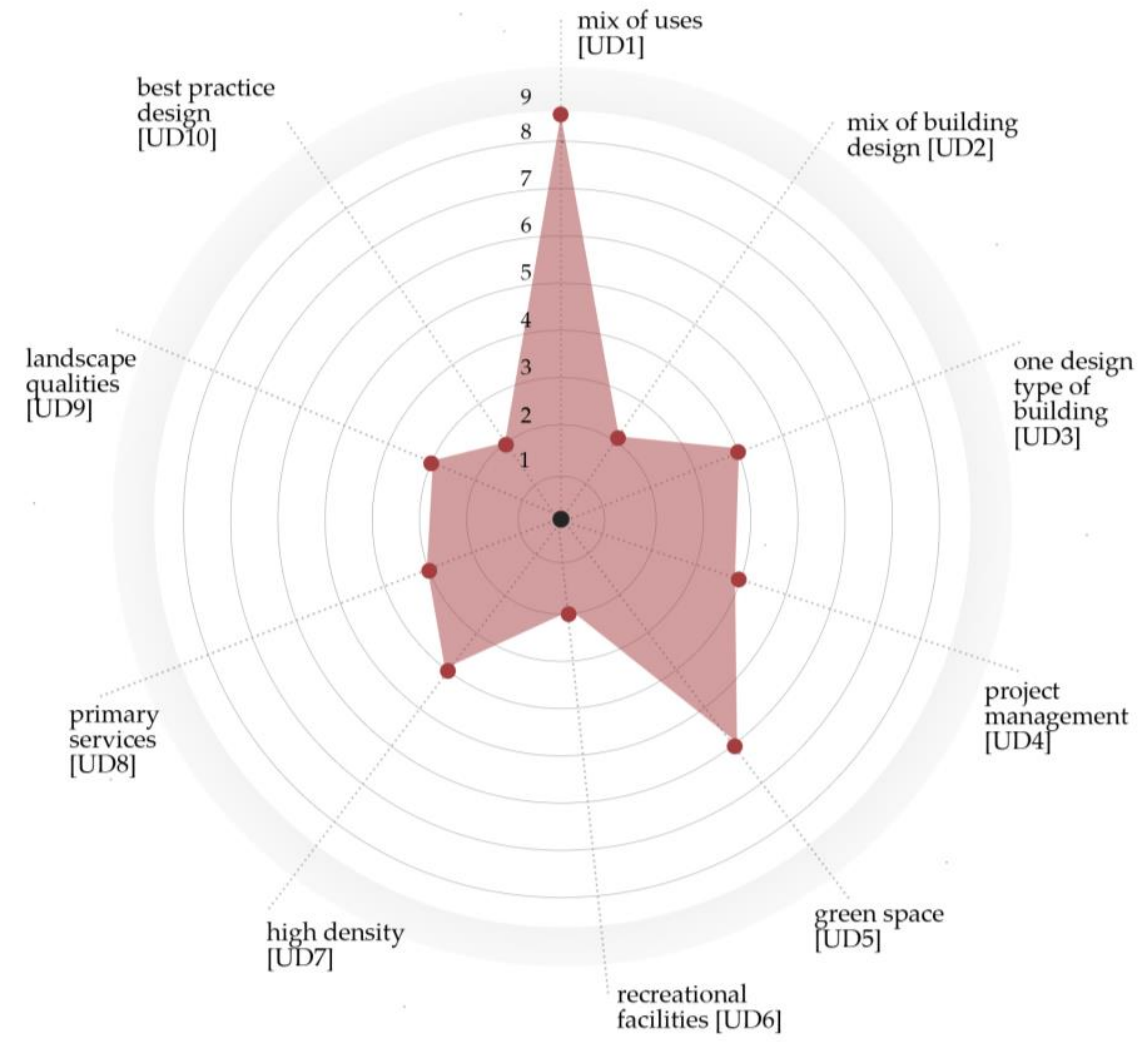

Figure 5. Presence of elements related to the urban design dimension based on the considered case studies. 
From the urban design point of view (Figure 5), the actions that are most frequently adopted are those regarding the development of different building designs and mixed uses, allowing the combination of different services and facilities (schools, nursery schools, youth facilities, civic meeting places, market places as well as leisure and play areas) with the residential functions. High-density areas are also encouraged, in order to reduce soil consumption and to increase the number of green spaces. Apart from this, the success of these projects also results from the application of different tools to accompany the developments and to gather specific objectives and requirements. The use of specifically selected tools, the definition of plans and the creation of multidisciplinary technical group allow for efficient process management, and to guarantee high-quality standards. All these aspects are considered in Figure 5 as the project management indicator.

As mentioned in Section 3, the environmental elements are not considered separately in order to avoid unnecessary replication: in fact, many actions adopted from an energy, social, mobility and urban design point of view are properly aimed at improving environmental conditions. When the environmental component has prevailed with respect to the others, it was considered in the energy dimension in Table 2.

\subsection{Theoretical and Empirical Indicators}

With the aim of better investigating if correspondence between theoretical reflections and empirical evidence exists in the context of eco-districts or sustainable neighborhoods, a final analysis was developed. Starting from the integrated principles for sustainable urban neighborhoods and related indicators as proposed by Luederitz [34], we searched for their adoption in previously examined experiences (Table 3). In particular, Table 3 shows, at the same time, the connection among Luederitz indicators and the sub-dimensions of urban sustainability, which are in their turn connected to the actions adopted by the different cities and reported in Table 2. Considering, for instance, the case of the indicator "Comprehensive water management" under the second principle, "Sustainable urban metabolism": in terms of urban sustainable development, this indicator can be related to the Energy dimension, with specific reference to the sub-categories of water separation and treatment (E2), water collection (E3), water re-use (E4) and green roofs (E10). Table 3 also reports the sites in which specific actions related to the considered indicator have been implemented.

In general, it is possible to state that many of the actions adopted in the analyzed eco-districts (Table 2) take into account most of the Luederitz sustainability principles and indicators. However, more efforts are needed to better understand the impact of some of the considered principles, such as "cater for resilient neighborhoods" (sixth principle), "satisfaction of human need" (eighth principle), "consider neighborhood impact on the wider environment" (ninth principle) and partially the fourth principle "cater for a livable and vibrant neighborhood".

In particular, for the sixth one, an interactive and adaptive process, as well as the adoption of precaution and adaptation actions to climate change [55-57] are essentially missing in the case studies analyzed. Constant monitoring systems should be developed in order to avoid climate change impact and risks [58]. In terms of practical actions, the only monitoring system employed was that adopted by the district of Greenwich Millennium Village (London), but only for public transport, so, this was more related to the analysis of residents' behavior (Luederitz indicator in principle III). However, also in Luederitz [34], the proposals of an interactive and adaptive process are only preliminary and quite fuzzy in the strategies to be adopted. Attempts to involve different stakeholders in the project and to accompany the developments with tools were tested by some districts, even if these strategies were limited to the project phase.

Another critical aspect highlighted by this comparison is related to the inclusion of marginalized stakeholders, as shown in the eighth principle. The analysis of the case studies does not, and cannot, straightforwardly provide a way to deal with this critical aspect. However, it remains a desired and crucial goal, even if few proposals on how to address it are given. 
Table 3. Theoretical indicators proposed by Luederitz and their relation to urban sustainability dimensions.

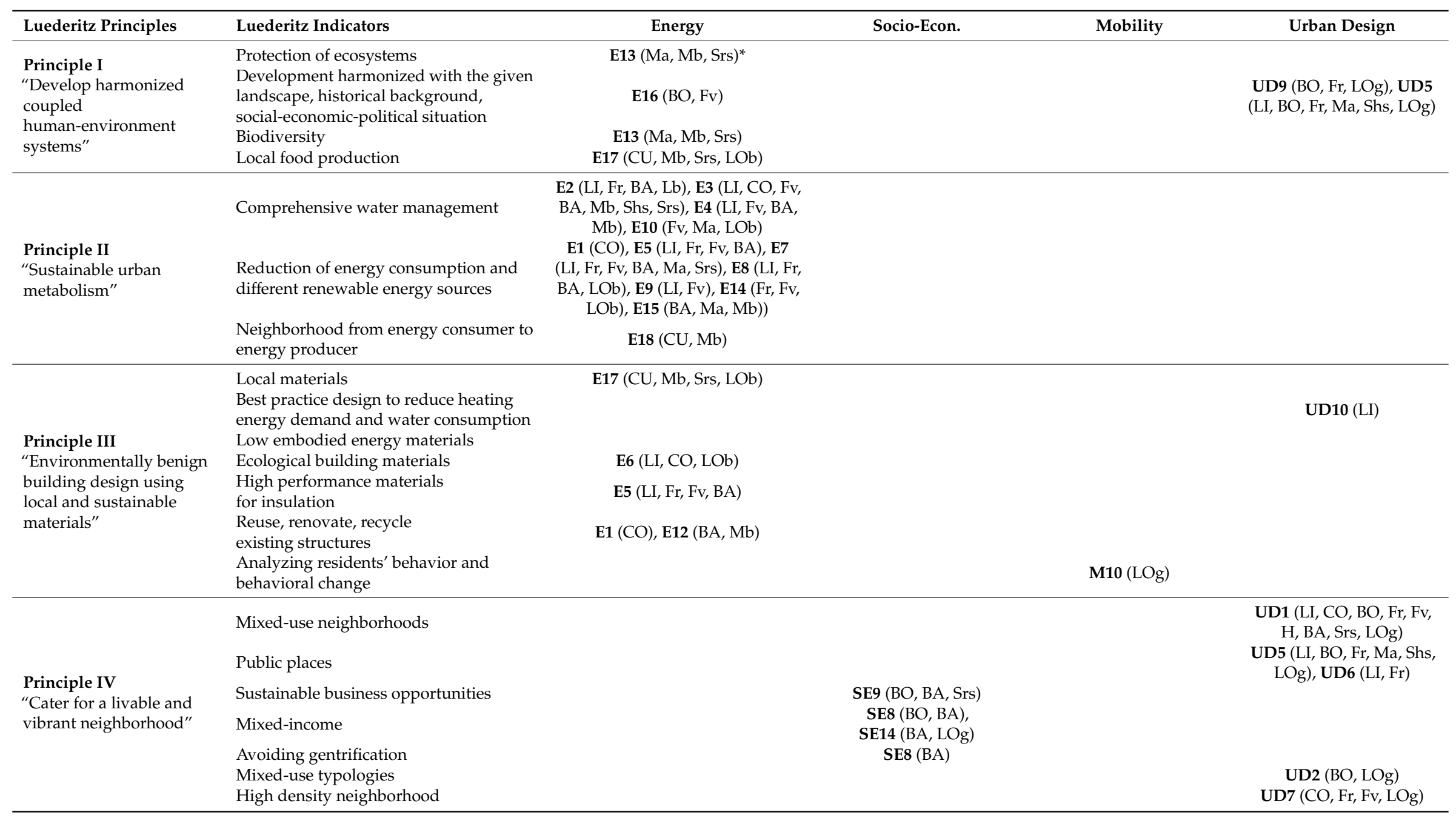


Table 3. Cont

\begin{tabular}{|c|c|c|c|c|c|}
\hline Luederitz Principles & Luederitz Indicators & Energy & Socio-Econ. & Mobility & Urban Design \\
\hline $\begin{array}{l}\text { Principle V } \\
\text { "Provide compact } \\
\text { development and } \\
\text { integrated sustainable } \\
\text { mobility" }\end{array}$ & $\begin{array}{l}\text { Primary services and daily needs } \\
\text { Good public transport } \\
\text { Reduce motorized transportation } \\
\text { Streets as public place } \\
\text { Contiguous compact neighborhoods }\end{array}$ & & & $\begin{array}{c}\text { M1 (LI, CO, BO, Fr, Fv, } \\
\text { Ma, Shs), M2 (LI, BA), M3 } \\
\text { (LI, Srs, LOg) } \\
\text { M5 (Fr, Fv, BA, LOg), M6 } \\
\text { (LI, Fr, Fv, LOg), M8 (Ma, } \\
\text { Lob, LOg) } \\
\text { M4 (LI, Fr, Fv, BA, Srs, } \\
\text { LOg), M5 (Fr, Fv, } \\
\text { BA, LOg) }\end{array}$ & UD8 (LI, Fv, LOg) \\
\hline $\begin{array}{l}\text { Principle VI } \\
\text { "Cater for resilient } \\
\text { neighborhoods" }\end{array}$ & Interactive and adaptive process & & $\begin{array}{l}\text { SE13 (H, BA, Mb, Srs, } \\
\text { LOg) }\end{array}$ & & UD4 (LI, H, BA, Mb) \\
\hline $\begin{array}{l}\text { Principle VII } \\
\text { "Ensure democratic } \\
\text { governance and empower } \\
\text { neighborhood residents" }\end{array}$ & $\begin{array}{l}\text { Residents' engagement } \\
\text { Education facilities and workshop } \\
\text { opportunities for knowledge exchange }\end{array}$ & & $\begin{array}{c}\text { SE1 (LI, BO, CU, BA, Ma), } \\
\text { SE10 (CU, BA) } \\
\text { SE2 (LI, CO, BO, H, } \\
\text { BA, Ma) }\end{array}$ & & \\
\hline $\begin{array}{l}\text { Principle VIII } \\
\text { "Satisfaction of human } \\
\text { needs" }\end{array}$ & $\begin{array}{l}\text { Integration of marginalized population } \\
\text { and mitigate adverse impacts on } \\
\text { disadvantaged groups }\end{array}$ & & SE8 (BO, BA) & & \\
\hline $\begin{array}{l}\text { Principle IX } \\
\text { "Consider neighborhood } \\
\text { impact on the wider } \\
\text { environment" }\end{array}$ & $\begin{array}{l}\text { Neighborhood as showcase to spread } \\
\text { sustainable measures to the broader city }\end{array}$ & & SE3 (LI), SE13 (LOg) & & \\
\hline
\end{tabular}

${ }^{*} \mathrm{LI}$ = Linz; CO = Copenhagen; BO = Bordeaux; Fr = Freiburg (Riesfield); Fv = Freiburg (Vauban); H = Hanover; CU = Culemborg; BA = Barcelona; Ma = Malmo (Augustenborg);

$\mathrm{Mb}=$ Malmo (bo01); Shs = Stockholm (Hammarby Sjostad); Srs = Stockholm (Royal Seaport); LOb = London (BedZed); LOg = London (Greenwich Millennium Village). 
Similarly, measures for avoiding gentrification phenomena (in the fourth principle) are only partially considered. It seems that only the city of Barcelona in the project of Trinitat Nova has taken this problem into account, as reported in Table 2. In addition, an effort was made by Bordeaux and London (Greenwich Millennium Village) to provide, or at least to claim to provide, a certain quantity of affordable housing in their districts. On the contrary, some sustainable neighborhoods examples show an opposite trend: they directly promote the development of islands of green privilege and pure eco-branding policies with the clear intention of attracting higher-income inhabitants and investors, as Cucca [42] underlines in her critical reflection on sustainable neighborhoods.

Probably the greatest efforts are needed with respect to the ninth principle, "consider neighborhood impact on the wider environment". The idea to develop successful examples of sustainable neighborhoods as a showcase and to spread sustainable measures to the whole city is certainly a key challenge. First attempts have already been made in Sweden (Malmö and Stockholm), in Germany (Freiburg and Hanover) and in the UK (London in BedZed, Greenwich Millenium Village and Royal Seaport project), where, starting from a project, similar or alternative solutions were proposed so to spread a more sustainable approach at the broader scale.

In contrast, some initiatives developed by the eco-districts examined lack in Luederitz's principles. One of these is the E11 indicator related to the adoption of quality control systems and certification. The inclusion of such initiatives certifies the achievement of high performance in key areas of environmental and human health. Instead, from a mobility point of view, some actions are totally missing in Luederitz's remarks, even if they seem quite prominent in future urban strategies, such as the diffusion of electric vehicles and car-pooling and car-sharing initiatives.

\section{Conclusions and Future Perspectives}

This article provided a review of the literature that deals with the different ways of understanding sustainable and smart urban ideas. In particular, it investigated the meaning of smart urbanism and sustainable neighborhoods (or eco-districts) from both a theoretical point of view and through a literature review of the main experiences in the domain of sustainable neighborhoods and/or eco-districts in Europe.

The main elements characterizing the theoretical discourses on such sustainable and smart models at a district scale were then further investigated in European case studies present in the relevant academic literature, using an analytical framework that combined findings coming from different approaches $[34,37]$. In line with the relevant literature on sustainability development [1,16,54,59-62], different dimensions have been taken into account simultaneously for the analysis of the considered experiences, that range from environmental impacts to social aspects, from energy performance to economic benefit. The comparison proposed highlights similarities and differences among those virtuous examples of sustainable neighborhoods or eco-districts, and, at the same time, it allowed reflection upon the potentials and pitfalls of the proposed analytical framework.

From the analysis of the results, it emerges that the energy aspects are the most connected in the projects under examination, thus highlighting the important consideration that efficiency and technology-oriented approaches have deserved in the selected case studies. It has to be mentioned that the recent literature in the context of sustainable cities has quite a controversial approach towards this technological trend in urban development. On one hand, the benefits delivered from the technological projects, such as photovoltaic panels and energy efficiency measures, are clear [63-65]; on the other hand, different authors provide evidence of the risk of producing "non democratic self-learning systems" that are independent from humans [66-68].

The most relevant element emerging from the analysis concerns a lack of research and investigation on those aspects related to the social dimension of sustainability [69], such as the inclusion of marginalized stakeholders. This evidence is possibly symptomatic of the scarce critical flavor that characterizes most literature concerning the concepts of smart urbanism and smart city, on which the analysis is largely built, and that constitutes the main paradigm that frames the great majority of the 
examples explored. Inverting this trend is particularly important for the future development of our cities, in order to avoid the risk of favoring the creation of "island[s] of green privilege" [52]. Cucca [42] addresses the particular issues of the social impact of sustainable neighborhood interventions in terms of green gentrification, by comparing the cases of Copenhagen and Vienna. She touches upon the risks of self-segregation into islands of green privilege, as well as of the promotion of pure eco-branding policies. For this reason, future research in the field of sustainable neighborhoods should further explore the social dimension, with special attention towards the phenomena of segregation and gentrification.

A final consideration inspired by the analysis proposed concerns the actual potential for transferability or upscaling of sustainable neighborhoods or eco-districts experiences, and hence the actual impact that experiences that are successful in one context may generate if transferred to another context or taken as an example by higher scale policy [31,32]. An example of this is found in Fitzgerald and Lenhart [52], who reflect upon the current potential for interventions in eco-districts and sustainable neighborhoods to actually produce an impact in terms of climate change mitigation, and argue that the potential is higher when such initiatives contribute to setting higher standards for sustainable development in a given territory; this may be the same city where the neighborhood is located, its regional surroundings, the whole country, or emulating cities located in other contexts. In this light, the attitude of a city government towards the promotion of these kinds of intervention is of particular relevance, as is the intention to invest in them-not in order only to "eco-brand" the city in the face of potential investors, but to use them as a real test-bed for upgrading overall city sustainability. According to Fitzgerald and Lenhart [52], such upgrading may occur through a deliberate process of organizational learning that allows city planners and elected officials to learn from other experiences and to apply the lessons learnt. Moreover, it is particularly important for these players to reflect on the potential for the implemented innovative solution to be applied in less prosperous or low-income neighborhoods, and in so doing contributing to overcoming the inherent conflicts that often characterize the conciliation of the various dimensions of sustainability.

In conclusion, with the aim of investigating the concept of the eco-district/sustainable neighborhood in European countries, this analysis allows the identification of some similarities in the different exemplary case studies examined, as well as the understanding of some good (and less good) practices for future sustainable actions. However, this research also highlighted the complexity of ascribing strategies and experiences developed in very different cities to the concept of eco-district/sustainable neighborhood. For that reason, future perspectives and more insights on the matter are necessary. Firstly, with respect to the case studies considered, they should, for sure, be implemented in number in future analyses. Secondly, even though they are from European cities, the heterogeneity that characterizes this context may potentially undermine any attempt to replicate or upscale virtuous initiatives. The different stable and dynamic context factors strongly influence the transferability of policies (for an overview of spatial policy transfer potentials and pitfalls in the European context see [31]). Thirdly, and partially connected to the second reason, future perspectives could focus on how transferring some strategies in a specific case study or different contexts. Finally, future analyses should consider examples located in other countries for exploiting synergies between different spheres of interventions and for inspiration in terms of new conceptualizations and alternative approaches to the issues at stake (for instance, see [70] and [20]), and also because some differences in terms of climate, technical capabilities, socio-economic features, institutional and political configurations not only distinguish European and non-European countries, but also cities in Europe.

Author Contributions: Each section of the article was written thanks to the collaboration of all authors: Conceptualization, M.B., C.C., G.C. and M.S; Methodology, M.B., C.C., G.C. and M.S; Formal Analysis, M.B., C.C., G.C. and M.S; Investigation, M.B., C.C., G.C. and M.S; Writing-Original Draft Preparation, M.B., C.C., G.C. and M.S.; Writing-Review \& Editing, M.B., C.C., G.C. and M.S.

Funding: This research was funded by Department of Regional and Urban Studies and Planning (DIST) of Politecnico di Torino, grant number 60_RD119BOM01. 
Acknowledgments: The work illustrated in the present paper has been developed in the research project titled VALIUM (Valuation for Integrated Urban Management) that has been supported by the Department of Regional and Urban Studies and Planning-DIST ofPolitecnico di Torino.

Conflicts of Interest: The authors declare no conflicts of interest.

\section{References}

1. United Nations, Department of Economics and Social Affairs, Population Division. The World's Cities in 2018; United Nations: New York, NY, USA, 2018.

2. Grubler, A.; Bai, X.; Buettner, T.; Dhakal, S.; Fisk, D.J.; Ichinose, T.; Keirstead, J.E.; Sammer, G.; Satterthwaite, D.; Schulz, N.B.; et al. Urban Energy Systems. In Global Energy Assessment (GEA); Johansson, T.B., Nakicenovic, N., Patwardhan, A., Gomez-Echeverri, L., Eds.; Cambridge University Press: Cambridge, UK, 2012.

3. Kourtit, K.; Nijkamp, P. Big data dashboards as smart decision support tools for $i$-cities-An experiment on stockholm. Land Use Policy 2018, 71, 24-35. [CrossRef]

4. Mondini, G. Valutazioni integrate per la gestione delle nuove sfide sociali. Valori e Valutazioni 2016, 17, 15-17.

5. Cotella, G.; Crivello, S. The Macroregional Geopolitics of Energy Security: Towards a New Energy World Order? In Low-Carbon Energy Security from a European Perspective; Academic Press: Cambridge, MA, USA, 2016; ISBN 9780128029879.

6. Bottero, M.; D'Alpaos, C.; Oppio, A. Ranking of Adaptive Reuse Strategies for Abandoned Industrial Heritage in Vulnerable Contexts: A Multiple Criteria Decision Aiding Approach. Sustainability 2019, 11, 785. [CrossRef]

7. Bottero, M.; Comino, E.; Dell'Anna, F.; Dominici, L.; Rosso, M. Strategic Assessment and Economic Evaluation: The Case Study of Yanzhou Island (China). Sustainability 2019, 11, 1076. [CrossRef]

8. Brandon, P.S.; Lombardi, P. Evaluating Sustainable Development in the Built Environment; John Wiley \& Sons: Hoboken, NJ, USA, 2010; ISBN 978-1405192583.

9. Luque-Ayala, A.; Marvin, S. Developing a critical understanding of smart urbanism? Urban Stud. 2015, 52, 2105-2116. [CrossRef]

10. Santangelo, M.; Aru, S.; Pollio, A. Smart city. In Ibridazioni, Innovazioni e Inerzie Nelle Città Contemporanee; Carocci Ed.: Roma, Italy, 2013; ISBN 9788843072811.

11. Hollands, R.G. Will the real smart city please stand up? City 2008, 12, 303-320. [CrossRef]

12. Galloway, A. Intimations of everyday life: Ubiquitous computing and the city. Cult. Stud. 2004, 18, 384-408. [CrossRef]

13. Klauser, F.; Paasche, T.; Söderström, O. Michel Foucault and the Smart City: Power Dynamics Inherent in Contemporary Governing through Code. Environ. Plan. D Soc. Space 2014, 32, 869-885. [CrossRef]

14. Murgante, B.; Borruso, G. Smart cities in a smart world. In Future City Architecture for Optimal Living; Rassia, S., Pardalos, P., Eds.; Springer Verlag: Berlin, Germany, 2015; pp. 13-35.

15. Cotella, G.; Crivello, S.; Karatayev, M. European Union Energy Policy Evolutionary Patterns. In Low-Carbon Energy Security from a European Perspective; Elsevier BV: Amsterdam, The Netherlands, 2016; pp. 13-42.

16. European Commission. European Commission the Strategic Energy Technology (SET) Plan; Publications Office of the European Union: Luxembourg, 2017; ISBN 978-92-79-74277-4.

17. Kitchin, R. The real-time city? Big data and smart urbanism. GeoJournal 2014, 79, 1-14. [CrossRef]

18. Allam, Z.; Newman, P. Redefining the Smart City: Culture, Metabolism and Governance. Smart Cities 2018, 1, 4-25. [CrossRef]

19. Dabeedooal, Y.J.; Dindoyal, V.; Allam, Z.; Jones, D.S. Smart Tourism as a Pillar for Sustainable Urban Development: An Alternate Smart City Strategy from Mauritius. Smart Cities 2019, 2, 153-162. [CrossRef]

20. Allam, Z. The Emergence of Anti-Privacy and Control at the Nexus between the Concepts of Safe City and Smart City. Smart Cities 2019, 2, 96-105. [CrossRef]

21. Datta, A. New urban utopias of postcolonial India. Dialog Hum. Geogr. 2015, 5, 3-22. [CrossRef]

22. Deakin, M.; Allwinkle, S. Urban Regeneration and Sustainable Communities: The Role of Networks, Innovation, and Creativity in Building Successful Partnerships. J. Urban Technol. 2007, 14, 77-91. [CrossRef]

23. Leydesdorff, L. The triple helix: An evolutionary model of innovations. Res. Policy 2000, 29, $243-255$. [CrossRef]

24. Graham, S. Splintering Urbanism; Routledge: Abington, UK, 2002; ISBN 9780203452202. 
25. Allam, Z.; Newman, P. Economically Incentivising Smart Urban Regeneration. Case Study of Port Louis, Mauritius. Smart Cities 2018, 1, 53-74. [CrossRef]

26. Allam, Z.; Dhunny, A.Z.; Siew, G.; Jones, D.S. Towards Smart Urban Regeneration: Findings of an Urban Footprint Survey in Port Louis, Mauritius. Smart Cities 2018, 1, 121-133. [CrossRef]

27. Cotella, G. The Urban Dimension of EU Cohesion Policy. In Territorial Cohesion. The Urban Dimension; Medeiros, E., Ed.; Springer: Berlin, Germany, 2019; pp. 133-151. ISBN 978-3-030-03386-6.

28. Hollands, R.G. Critical interventions into the corporate smart city. Camb. J. Reg. Econ. Soc. 2015, 8, 61-77. [CrossRef]

29. Söderström, O.; Paasche, T.; Klauser, F. Smart cities as corporate storytelling. City 2014, 18, $307-320$. [CrossRef]

30. Choguill, C.L. Developing sustainable neighbourhoods. Habitat Int. 2008, 32, 41-48. [CrossRef]

31. Cotella, G.; Janin Rivolin, U.; Santangelo, M. Transferring Good Territorial Governance in Europe: Opportunities and Barriers' In Territorial Governance across Europe: Pathways, Practices and Prospects; Schmidt, P., Van Well, L., Eds.; Routledge: London, UK, 2015; pp. 238-253. ISBN 978-1-138-86087-2.

32. Cassen, C.; Hamdi-Chérif, M.; Cotella, G.; Toniolo, J.; Lombardi, P.; Hourcade, J.C. Low Carbon Scenarios for Europe: An Evaluation of Upscaling Low Carbon Experiments. Sustainability 2018, 10, 848. [CrossRef]

33. Lützkendorf, T.; Balouktsi, M. Assessing a Sustainable Urban Development: Typology of Indicators and Sources of Information. Procedia Environ. Sci. 2017, 38, 546-553. [CrossRef]

34. Luederitz, C.; Lang, D.J.; Von Wehrden, H. A systematic review of guiding principles for sustainable urban neighborhood development. Landsc. Urban Plan. 2013, 118, 40-52. [CrossRef]

35. Valkenburg, G.; Cotella, G. Governance of energy transitions: About inclusion and closure in complex sociotechnical problems. Energy Sustain. Soc. 2016, 6, 739. [CrossRef]

36. Kyvelou, S.; Sinou, M.; Baer, I.; Papadopoulos, T. Sustainability in Energy and Buildings; Howlett, R.J., Jain, L.C., Lee, S.H., Eds.; Smart Innovation, Systems and Technologies; Springer: Berlin/Heidelberg, Germany, 2011; Volume 7, ISBN 978-3-642-17386-8.

37. Medved, P. A contribution to the structural model of autonomous sustainable neighbourhoods: New socio-economical basis for sustainable urban planning. J. Clean. Prod. 2016, 120, 21-30. [CrossRef]

38. Medved, P. Exploring the 'Just City principles' within two European sustainable neighbourhoods. J. Urban Des. 2018, 23, 414-431. [CrossRef]

39. Medved, P. Leading sustainable neighbourhoods in Europe: Exploring the key principles and processes. Urbani izziv 2017, 28, 107-121. [CrossRef]

40. Schroepfer, T.; Hee, L. Emerging Forms of Sustainable Urbanism: Case Studies of Vauban Freiburg and solarCity Linz. J. Green Build. 2008, 3, 65-76. [CrossRef]

41. Marique, A.F.; Reiter, S. Towards more sustainable neighbourhoods: Are good practices reproducible and extensible? A review of a few existing "sustainable neighbourhoods". In Proceedings of the PLEA 2011-27th Conference on Passive and Low Energy Architecture, Louvain-la-Neuve, Belgium, 13-15 July 2011.

42. Cucca, R. The social impact of green urban renewal in two European Capital Cities: Copenhagen and Vienna in comparison. In Proceedings of the Environmental Justice in the Anthropocene Symposium 2017, Fort Collins, CO, USA, 24-25 April 2017.

43. Caiati, G.; Declich, A. The social nature of materials. A brief overview and two case studies concerning the Energy transition context. Matér. Tech. 2016, 104, 603. [CrossRef]

44. Flurin, C. Eco-districts: Development and Evaluation. A European Case Study. Procedia Environ. Sci. 2017, 37, 34-45. [CrossRef]

45. Tozzi, P. Participative stakes in the adaptation of urban planning towards sustainability-A close examination of projects in some eco-districts of the city of Bordeaux. Sud-Ouest Eur 2014, 37, 105-116. [CrossRef]

46. Machline, E.; Pearlmutter, D.; Schwartz, M. Parisian eco-districts: Low energy and affordable housing? Build. Res. Inf. 2018, 46, 636-652. [CrossRef]

47. Zaręba, A.; Krzemińska, A.; Łach, J. Energy sustainable cities. From eco villages, eco districts towards zero carbon cities. E3S Web Conf. 2017, 22, 199. [CrossRef]

48. Hagen, B.; Nassar, C.; Pijawka, D. The Social Dimension of Sustainable Neighborhood Design: Comparing Two Neighborhoods in Freiburg, Germany. Urban Plan. 2017, 2, 64. [CrossRef]

49. Kasioumi, E. Sustainable urbanism: Vision and planning process through an examination of two model neighborhood developments. Berkeley Plan. J. 2011, 24, 91-114. [CrossRef] 
50. Vall-Casas, P.; Koschinsky, J.; Mendoza-Arroyo, C.; Benages-Albert, M. Retrofitting suburbia through systemic densification: The case of the metropolitan region of Barcelona. J. Archit. Plann. Res. 2016, 33, 45-70.

51. Farreny, R.; Oliver-Solà, J.; Montlleó, M.; Escribà, E.; Gabarrell, X.; Rieradevall, J. The ecodesign and planning of sustainable neighbourhoods: The Vallbona case study (Barcelona). Inf. la Construcción 2011, 63, 115-124. [CrossRef]

52. Fitzgerald, J.; Lenhart, J. Eco-districts: Can they accelerate urban climate planning? Environ. Plan. C Gov. Policy 2016, 34, 364-380. [CrossRef]

53. Bossuyt, D.M.; Savini, F. Urban sustainability and political parties: Eco-development in Stockholm and Amsterdam. Environ. Plan. C Politics Space 2018, 36, 1006-1026. [CrossRef]

54. United Nations. The Sustainable Development Goals Report; United Nations Publ.: New, York, NY, USA, 2017.

55. Datola, G.; Bottero, M.; De Angelis, E. How Urban Resilience Can Change Cities: A System Dynamics Model Approach. In Proceedings of the International Conference on Computational Science and Its Applications (ICCSA 2019), Saint Petersburg, Russia, 1-4 July 2019.

56. Assumma, V.; Bottero, M.; Monaco, R.; Soares, A.J. An integrated evaluation model for shaping future resilient scenarios in multi-pole territorial systems. Environ. Territ. Model. Plan. Des. 2018, 4, 17-24.

57. Bottero, M.; Ferretti, V. Integrating the analytic network process (ANP) and the driving force-pressurestate-impact-responses (DPSIR) model for the sustainability assessment of territorial transformations. Manag. Environ. Qual. An Int. J. 2010, 21, 618-644. [CrossRef]

58. Chelleri, L.; Waters, J.J.; Olazabal, M.; Minucci, G. Resilience trade-offs: Addressing multiple scales and temporal aspects of urban resilience. Environ. Urban. 2015, 27, 181-198. [CrossRef]

59. IEA. IEA Global Energy and CO2 Status Report 2018; OECD/IEA: Paris, France, 2019.

60. IEA. IEA 2018 World Energy Outlook-Executive Summary; OECD/IEA: Paris, France, 2018.

61. OECD. OECD Regulatory Policy Outlook 2018; OECD: Paris, France, 2018.

62. IEA. World Energy Balances 2018; IEA: Paris, France, 2018; ISBN 9789264301559.

63. Becchio, C.; Bottero, M.C.; Corgnati, S.P.; Dell'Anna, F. Decision making for sustainable urban energy planning: An integrated evaluation framework of alternative solutions for a NZED (Net Zero-Energy District) in Turin. Land use policy 2018, 78, 803-817. [CrossRef]

64. Caprioli, C.; Bottero, M.C. Agent-based modelling and Geographic Information System for the evaluation of eco-district's scenarios. In Proceedings of the Environmental and territorial modelling for planning and design; Leone, A., Gargiulo, C., Eds.; FedOAPress: Naples, Italy, 2018; pp. 35-45.

65. D'Alpaos, C. The value of flexibility to switch between water supply sources. Appl. Math. Sci. 2012, 6, 6381-6401.

66. Foth, M. Participatory urban informatics: Towards citizen-ability. Smart Sustain. Built Environ. 2018, 7, 4-19. [CrossRef]

67. Hale, L.A. Anthropocentric urban sustainability: Human significance in building automation. Sustain. Cities Soc. 2018, 42, 423-433. [CrossRef]

68. Yigitcanlar, T.; Kamruzzaman, M.; Foth, M.; Sabatini-Marques, J.; Da Costa, E.; Ioppolo, G.; Sabatini, J. Can cities become smart without being sustainable? A systematic review of the literature. Sustain. Cities Soc. 2019, 45, 348-365. [CrossRef]

69. Las Casas, G.; Scorza, F.; Murgante, B. New urban agenda and open challenges for urban and regional planning. In Proceedings of the ISHT: International Symposium on New Metropolitan Perspectives, Reggio Calabria, Italy, 22-25 May 2018.

70. Allam, Z. Achieving Neuroplasticity in Artificial Neural Networks through Smart Cities. Smart Cities 2019, 2, 118-134. [CrossRef]

(C) 2019 by the authors. Licensee MDPI, Basel, Switzerland. This article is an open access article distributed under the terms and conditions of the Creative Commons Attribution (CC BY) license (http://creativecommons.org/licenses/by/4.0/). 